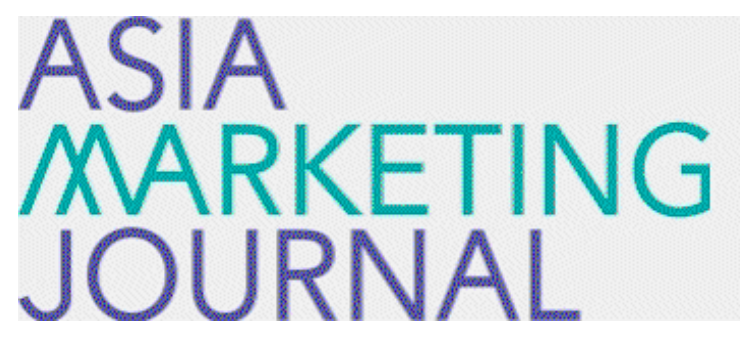

ASIA MARKETING JOURNAL

Volume 19 | Issue 3

Article 5

10-31-2017

\title{
ASIA MARKETING JOURNAL Vol.19 No.3 목차
}

Follow this and additional works at: https://amj.kma.re.kr/journal

Part of the Marketing Commons

\section{Recommended Citation}

(2017) "ASIA MARKETING JOURNAL Vol.19 No.3 목차," Asia Marketing Journal: Vol. 19 : Iss. 3 , Article 5. Available at: https://doi.org/10.53728/2765-6500.1455

This Article is brought to you for free and open access by Asia Marketing Journal. It has been accepted for inclusion in Asia Marketing Journal by an authorized editor of Asia Marketing Journal. 


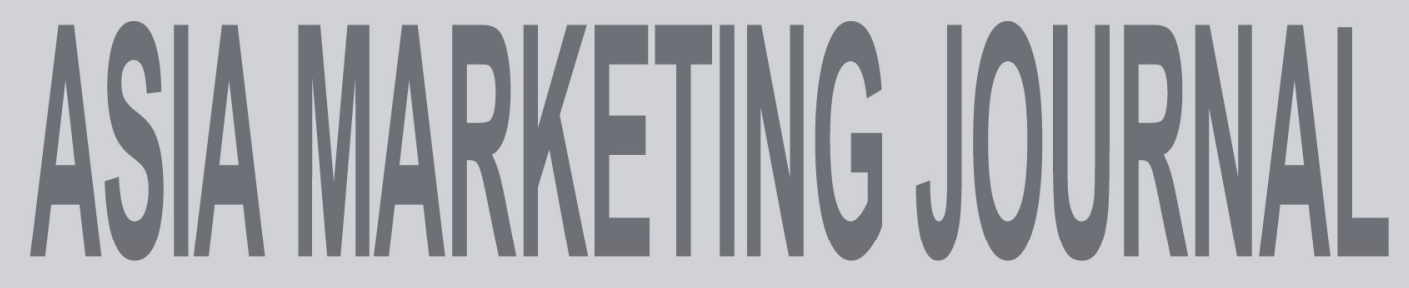

\section{Vol. 19 No. 03 October 2017}

\section{<Research Paper>}

Overcoming the Cause Marketing Paradox:

The Effect of Nostalgia on Charitable Giving and Happiness

Examining the Impact of Co-branding Service Failures on Consumer Evaluations

Effect of Motivation Type and Reward Uncertainty on Consumers' Marketing

Promotion Participation Yan-Jie Zhang · Youseok Lee · Sang-Hoon Kim

Effects of Individual Difference on Organizational Difference:

Perceived Training Effectiveness Model for Organizational Performance 